\title{
Exploring Primary School Mathematical Concepts in Gembira Dance
}

\author{
Neni Mariana, Trisya Maritaria \\ Department of Elementary Teacher Education \\ Universitas Negeri Surabaya \\ Surabaya, Indonesia \\ nenimariana@unesa.ac.id
}

\begin{abstract}
The purposes of this study were to explore an Indonesian creative dance called Gembira dance to find mathematical concepts and describe the views of teachers and students on the results of exploration. This study was qualitative research that used multi paradigms namely postmodernism, interpretivism, and criticalism. Techniques for collecting data used writing critical auto|etnography, writing as inquiry, postmodern interview, and data collection matrix. Maritaria's stories and experiences as a dancer, a dance teacher in an elementary school and an elementary school classroom teacher are being the narrative data of this study. The results of this study were elementary school mathematical concepts, including number concepts, number operation concepts, geometry and measurement concepts. In the view of teachers and students, these findings could be used as a source of mathematical learning based on the creative dance.
\end{abstract} school

Keywords-mathematical concepts; gembira dance; elementary

\section{INTRODUCTION}

Art is a manifestation of the existence of national identity in the form of expressions that contain cultural values. Art has moral messages that will be conveyed to art lovers in the form of symbols. The various levels of difficulty that exist in the arts do not make their important role disappear from national culture. There are two types of arts taught in Indonesian primary curriculum, called fine arts and performance. One form of performance is dance. According to Cvejic [1], dance is an expression of emotion and expression through motion.

In terms of education, at the elementary school level there are subjects of Cultural Arts and Crafts (SBDP) which contain dance arts. Through the 2013 curriculum students will think holistically because of the integration of all subjects including SBdP subjects with other subjects. Focusing on experience and impressions is the essence of education in Indonesia today. Speaking of dance in education, researchers will provide a review of the views of researchers in looking at dance with Mathematics based on the experience that has been passed by researchers themselves when elementary school.

My view of dance with mathematics

I started learning to dance since kindergarten. The dance that I often show on stage and competition is Gembira dance.
This Gembira Dance was taught by my extracurricular teacher when I was in elementary school. My teacher teaches various basic movements of dance, beats in dance music, and floor patterns. When I practice, I am always taught by counting techniques, which generally start from numbers 1 to 8 . Not infrequently also, pat into the tempo media on the dance. My teacher is also often angry when the position of the hands or feet is not right. Especially when mendhak (lower the body), body gestures are very much considered and bend the legs. My teacher simply conveyed the techniques in dance, for example: the position of the hand should be straight, the position of the foot mendhak or the position of the body should not be bent, when music slowly or quickly still had to pay attention to the expression of the dancer. In addition, my teacher also told me about the types of floor patterns in the dance, some of which were diagonal, horizontal, and vertical. The experience that I got in learning to dance, I applied it when teaching extracurricular dance in two schools. It once crossed my mind that there was involvement of Mathematics with dance. Seen from how to calculate each change of motion and when forming a floor pattern. I teach floor patterns to make shape transitions for example from circles to horizontal. But my mind ignored Mathematics. During the school period the class teacher never discussed the connection between Mathematics and dance. That's where the action is ignorant of my thinking about Mathematics. Where possible in the dance there is an element of Mathematics. Especially when I was in elementary school, Mathematics became my mortal enemy. I am more comfortable dancing for hours than learning Mathematics. Just looking at the numbers makes me dizzy. Actually, I really want to overcome fear with Mathematics when elementary school. Through hobbies, I want to be able to love Mathematics. How do I change my mind set towards creepy Mathematics? Is it possible to love dancing, I can also love Mathematics? Will there be Mathematics in dance? Then what part of the Mathematics concept can I explore from dance? What is my role as a teacher candidate and as an extracurricular teacher to integrate dance with Mathematics? I want to make a change regarding the mind set about Mathematics. Hope I can channel the cultural love through the field of science so that I don't experience the things I feel from a negative point of view. So how do I change their mind set, including myself?

Based on the story, the researcher realized that during this time the dance extracurricular teacher and research class 
teacher did not show any connection to mathematical material with dance or dance with mathematics. The experience had an impact when researchers taught extracurricular dance, the researchers also did not provide a mathematical connection picture that existed in the dance. Likewise, when researchers teach in class during mathematical material, researchers also do not relate dance to learning. So, that it looks like there is a separation of subjects, namely between mathematics and dance. Even though in the story the researchers found Mathematics as a basis for making dance moves such as numbers, flat shapes, lines and angles. Numbers are used to determine the count of motion and tempo in dance which generally uses numbers 1 to 8 . The pattern of the floor in dance will form a line, angle, and flat shape. Angles are used to determine the position of the dancer's feet and hands. On the other hand, according to Taylor [2] in STEAM's theory (Science, Technology, Engineering and Mathematics), to overcome global problems and prepare advances in the field of technology, the first step is needed with the need to integrate art with Mathematics.

The researcher gave several questions to several students and parents to find out other people's views about the relationship between Mathematics and dance. The response from several fourth-grade students of Babatan 1 elementary school who participated in dance extracurricular activities, some of these students did not understand the connectio between Mathematics and dance. In addition, the statement obtained by researchers from parents of students regarding Mathematics and dance is not unthinkable at all to associate the two because it is seen that there is no connection between Mathematics and dance. The researcher also gave questions to students of Muhammadiyah 1 Krian Sidoarjo elementary school who participated in dance extracurricular activities on Mathematics with dance but they could not argue to answer the researcher's questions. Meanwhile according to Mohan [3] Mathematics is a dance and vice versa dance is Mathematics.

Based on the researcher's own experience and the background of the researcher as well as theories, there is a connection between mathematics and dance. Researcher was interested in taking the title "Exploration of the Concept of Mathematics in Primary Schools in Gembira Dance". Therefore, researcher will explore elementary school math concepts in Gembira dance. The point is to find elementary school math concepts and describe the views of the teacher and the results of exploration.

\section{METHOD}

This study is a transformative qualitative study using multiparadigmatic. There are three combinations of paradigms namely Postmoderism, Interpretivism, and Criticalism. The steps in this study refer to 5 dimensions of knowledge by Taylor [4]. Next in conducting research, the following procedures of the research shown in Figure 1.

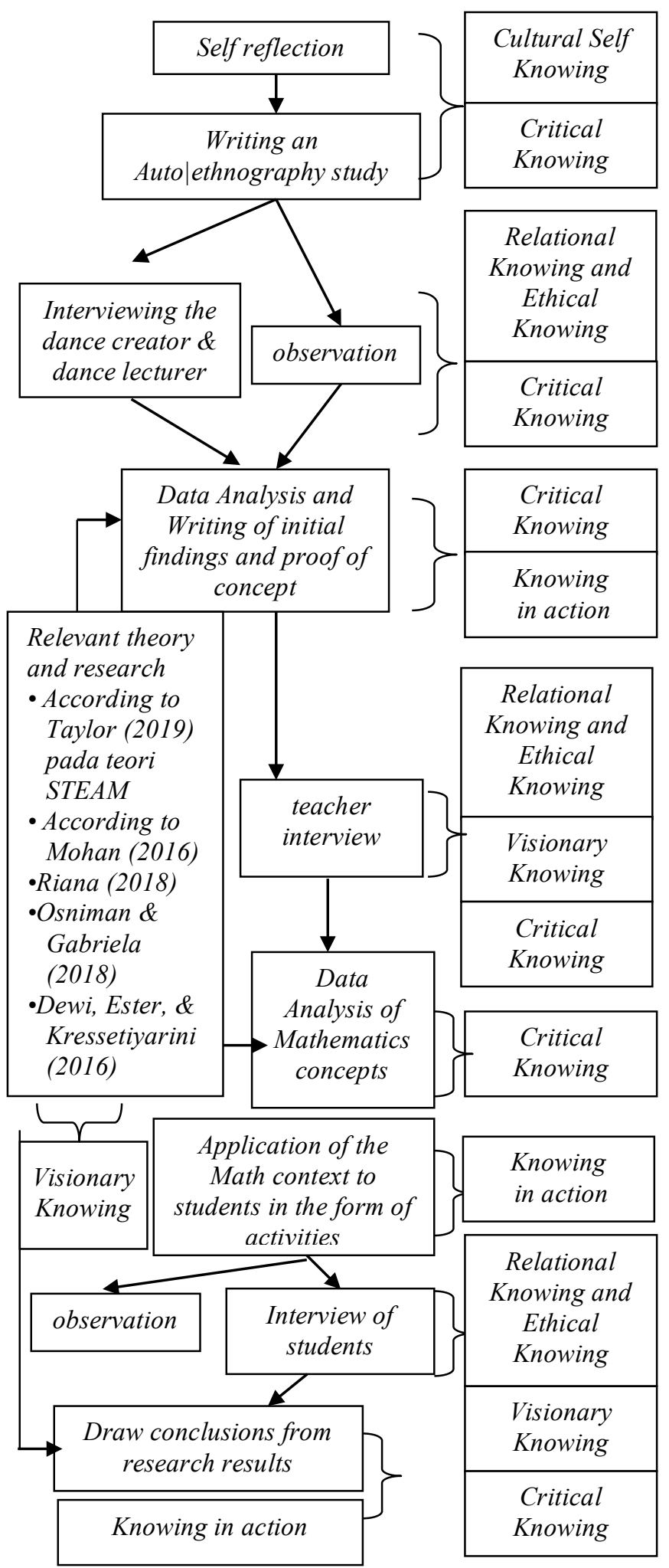

Fig. 1. Transformative research procedures

Based on the research procedure chart, it can be seen that the subject of this study consisted of researchers, dance actors, teachers, and students of Muhammadiyah 1 Krian Elementary School. 
Data collection was done using Writing Critical Auto Etnography Inquiry, Writing as techniques. Inquiry, and Postmodern Interview, and Data Collection Matrix. In the Data Writing Critical Auto | Etnography Inquiry technique, Autho ethnography will take the form of stories and poems. In the Writing as Inquiry technique data will be obtained in the form of narration. This narrative produces the mathematical concepts that exist in Gembira dance and is obtained through the discovery of new information from participants. Postmodern Interview will produce data in the form of interviews related to Gembira dance, mathematical concepts and contexts in the form of learning activities. The Data Collection Matrix will generate a record or list of collected data.

To prove the validity of the research and to be justified the authenticity and authenticity is a function of the data validity technique, the data validity techniques in transformative research are, Verisimilitude, Representation, Critical Reflexivity, Trustworthiness and Authenticity, Crystallization. When using the Verisimilitude technique, the reader feels that experiencing the same thing with the researcher is where the verisimilitude assessment lies. At the time of using Representation researchers became writers and also simultaneously paraphrased the results of the interviews into narrative forms. Whereas when using Critical Reflexivity researchers conduct self-reflection with all the questions that appear repeatedly about the concept of Mathematics in dance creations. Credibility, Transferability, Dependability, Confirmability are benchmarks of Trustworthiness [5]. The Credibility benchmark is determined through repeated research and member checking. The benchmark of Transferability is by giving a description of the story description in the background. Dependability benchmarks have a continuous writing style to see the changes that occur. The Confirmability benchmark is a confirmation from the expert on a story that makes the story can be used as data. When performing the Credibility data validity technique researchers will conduct member checking and re-confirmation, whether the written data is in accordance with what the respondent intended. Dependability is done when the researcher writes in the form of a story, and poetry will have a review. According to Mariana [6] fairness, ontological, educative, catalytic, and tactical are benchmarks of Authenticity. Authenticity is used to see the authenticity of the story, and the poetry that has been written. The term of fairness is determined through commensurate data and discusses the same subject matter. Ontological discontinuation will carry out reflections and discussions by researchers together with the teacher. And the last is Crystallization. Crystallization does not only see from a perspective that is compartmentalized but sees and makes a phenomenon interrelated with one another.

\section{RESULTS AND DISCUSSION}

\section{A. Dance in Curriculum 2013}

Based on the results of the auto|ethnography, the researcher tells of her experience of the doubts she experienced related to the relevance of mathematics to dance. Researchers know that when teaching in a classroom with Curriculum 2013 must link each subject according to basic competencies, one of which is to associate mathematics with dance. Although mathematics and dance are inherent in the researcher so far, the researchers did not consider and knew of any link between each other, but after researchers conducted interviews with respondents the researchers got a connection between mathematics and dance. It can be seen from the expressions of the respondents at the time of the interview. Researchers find out how the experience of respondents in the process of making dance. The researcher found the role of mathematics in making dance on the results of the discussion. When someone makes a dancer's position must be adjusted to the power points on the stage. The track and location of the dancer are very important, because they must be in accordance with the efficient calculation of the track. If the track is not accurately calculated, the track is not neat and must be changed according to the stage's strength point. In addition, there were opinions from the second respondent which strengthened the existence of mathematical relationships with dance, namely when making dance moves, movements would be calculated systematically, measurably, and surely. The same is true when making a dance accompaniment, which must be adjusted to each beat or rhythm. If the accompaniment is not in accordance with the beat, the dance accompaniment will not be made. This is in line with the opinions of social constructivists, namely according to their view, namely the existence of linkages and derivatives of culture, namely dance [7].

\section{B. Mathematical Concepts in Gembira Dance}

Talking about the connection between mathematics and dance, to find mathematical concepts contained in dance in detail, the researcher will try to write stories about her experience in dancing when she was in elementary school. The story of the researcher dancing Gembira dance to get the findings of mathematical concepts including, when calculating each motion starting from the count of 1 to 8 , the concept of natural numbers is found. The repetition of each movement counts the multiplication concept. In addition, the handwinding hand movement, which is the right-hand bending as it forms an angle of $45^{\circ}$ and the palm parallel to the forehead, then the fingers bounce, there is the concept of acute angles. There are also various angles, plane and characteristic when the researchers form zig-sag patterns, circles, and triangles.

In addition to the story of the researcher's experiences about dancing Gembira dance which is used as a data, researchers will also do Gembira dance exploration on the video. Video exploration carried out by researchers to explore in detail. Gembira dance videos are taken from the video of the Kembang Sore dance studio owned by Mr. Untung Mulyono as the creator of the dance. The results of the exploration of Gembira dance videos to find the concept of numbers, namely natural numbers. One of the counts of motion in the Gembira dance is $4 \times 8$. Starting from the count of 1 to 8 is a process of 1 movement, if 4 moves then the count will return to 1 to count 8 as much as 4. In addition, also found multiplication operations that are at repetition of motion. The repetition is done when motion for example $4 \times 8$ on the duration of the Gembira dance to $00.39-01.06$. The purpose of $4 \times 8$ is when the dancer moves the dance or the process of going 1 motion will be counted from numbers 1 to 8 , if the movement is carried out 4 times then the count will start from numbers 1 to 
8. The following are the results of Excited dance exploration with the operational mathematical concepts of multiplication and natural numbers,

TABLE I. Gembira DANCE DURATION

\begin{tabular}{|l|c|l|}
\hline No & Duration & Count \\
\hline 1 & $00.39-01.06$ & $(4 \times 8)$ \\
\hline 2 & $01.07-01.33$ & $(4 \times 8)$ \\
\hline 3 & $01.34-02.02$ & $(4 \times 8)$ \\
\hline 4 & $02.03-02.29$ & $(4 \times 8)$ \\
\hline 5 & $02.30-02.59$ & $(4 \times 8)$ \\
\hline 6 & $03.00-03.27$ & $(4 \times 8)$ \\
\hline 7 & $03.28-03.57$ & $(4 \times 8)$ \\
\hline 8 & $03.58-04.23$ & $(4 \times 8)$ \\
\hline 9 & $04.24-04.53$ & $(8 \times 8)$ \\
\hline 10 & $04.54-05.21$ & $(8 \times 8)$ \\
\hline 11 & $05.22-05.49$ & $(8 \times 8)$ \\
\hline 12 & $05.50-06.02$ & $(3 \times 8)$ \\
\hline 13 & $06.03-06.28$ & $(4 \times 8)$ \\
\hline 14 & $06.29-06.59$ & $(4 \times 8)$ \\
\hline 15 & $07.00-07.29$ & $(4 \times 8)$ \\
\hline 16 & $07.30-08.00$ & $(4 \times 8)$ \\
\hline & & \\
\hline
\end{tabular}

In addition to numbers, researchers also find geometric concepts and measurements that are the existence of points, lines, vertices, and angles. Points and lines appear when the dancer forms a parallel line pattern on the Gembira dance. The parable that one of the dancers is a point, while the combined dancer who forms a parallel position is a line. Angle points, various angles, and line segments are in various floor patterns formed in Gembira dance, namely parallelogram, circle, hexagon, pentagon, and triangle. In addition, there are angles, acute angles, obtuse angles, straight angles, and line segments also found in the Gembira dance movements like the following photo,

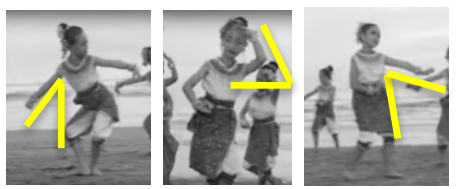

Fig. 2. Gembira dance hand movements form acute angles

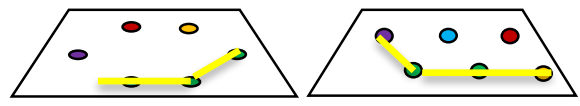

Fig. 3. The position of the dancer forms a obtuse angle

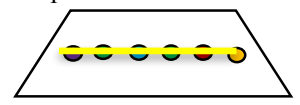

Fig. 4. The position of the dancer forms a straight angle
The next geometry concept found by researchers is a number pattern. The pattern of numbers found in Gembira dance, namely Jump walking while clapping forward and backward, Ciblon Sitting Down, and Cawuk Ukel Kembar.

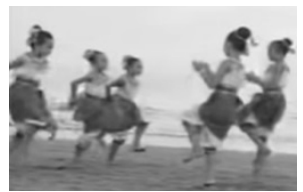

Fig. 5. Jump walking while clapping forward and backward

Jump walking while clapping forward and backward is by way of, 3 steps back and forth if calculated will form a pattern 36912

Fig. 6. Ciblon Sitting Down

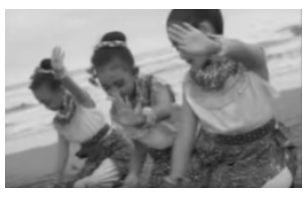

Ciblon sitting down is by moving the right ngrayung 2 times then left 2 times like taking water from back to front when calculated will form a pattern 2468

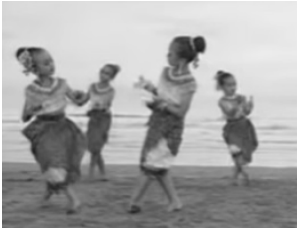

Fig. 7. Cawuk Ukel Kembar Motion

Cawuk ukel kembar is by way of the right foot tilted then the left mancat (crossing), then both hands twins ukel twins 2 times, followed by 2 times starting from the right. When calculated it will form a pattern 2468

2-dimensional figures are also found on the floor pattern. The floor pattern can form a flat shape, as for the types of flat shapes in the Gembira dance video, namely parallelogram, circle, hexagon, pentagon, and triangle. This pattern or movement of motion can contain mathematical concepts which are about the characteristics of a 2-dimensional figure and its kinds. The following is a picture of the floor pattern of each dance,

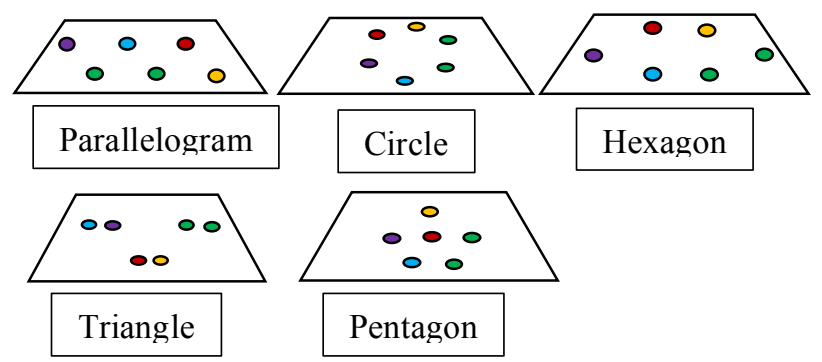

Fig. 8. The position of the dancer forms a flat shape 


\section{Adaptation to Learning}

The mathematical concepts found in the Gembira dance video are found in Basic competencies in class I, II, and III. Examples of some of the mathematical contexts found in Gembira Dance are in basic competencies 3.8: Know and determine the length and weight with non-standard units using concrete objects/situations. Can be implemented with a floor pattern that is by choosing several students, for example three students named Hendry, Aisyah and Claudia for lines forming horizontal lines then the students are asked for rows based on their height. Starting from the right side are the highest students, getting to the left means getting shorter. Other students are asked to determine who is taller/shorter and compare between the 3 students who have rows. Then the teacher can give questions to the students.

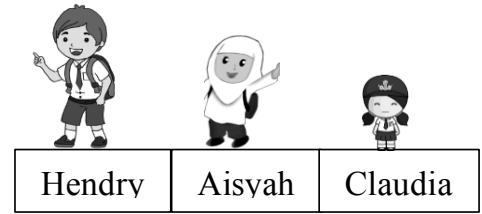

Example:

a) is higher than

b)___ the shortest girl among my friends.

c) From your friend in front, who has the highest body?

Not only the context, the researchers also made several questions related to the results of the discovery of mathematical concepts. the question is not far from mathematics with dance. The following is an example of a mathematical context problem,

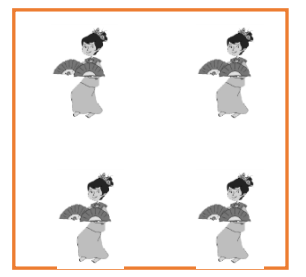

\section{Dari gambar di samping, posisi penari membentuk bangun datar....
a. Segitiga
b. Lingkaran
c. Persegi

Problem translation:

2. From the picture, the dancers' position form a plane called .... a. triangle

b. circle

c. square

Such a question can help students to develop their spatial ability. While dancing and take a position, they listen to teacher's instruction for example, form a square, form a circle, or form a line. While doing the floor plotting, students recognize the properties of plane shapes and arrange their movement position to fulfil the properties. This finding is related to Bresnahan's theory [8] which stated that when the dancer does the temporal moves, she applies her spatial parameters regarding her position to other dancers.

After exploring the dance, I was delighted by the researchers and video experience. Researchers have discovered mathematical concepts and made mathematical contexts. The researcher asked several respondents about their responses related to the results of the exploration of mathematical concepts in Gembira dance. Interviews conducted using postmodern interviews are possible to allow discussion with respondents. Some respondents revealed that there were those who were aware of the mathematical concepts in Gembira dance, but some respondents also stated otherwise. Respondents were also interested in applying the learning of mathematical contexts that had been found in the learning process because they felt that things were new and quite interesting and were still adapted to basic competencies.

After the researcher conducted an interview with the respondent, the researcher will also observe the students who were taught during the extracurricular dance. The reason for choosing students is taught by extracurricular researchers because it is in accordance with the auto/ethnography researcher. When doing dancing, activities using the mathematical concept of students interested and happy. Through the repetition at the time the activity took place, the student memorized it with a count without seeing the notes. This can be called number sense. According to Saleh [9] number sense is a person's sensitivity in giving an agile response or response at the time of spelling. The conclusions from the description of the results of interviews with students are that students are more interested and active when learning mathematics through dancing. From the results of exposure to auto|ethnography data, videos, and discussions with the teacher found the existing mathematical concepts. The following is a presentation on the results of exploring primary school mathematical concepts in Gembira dance.

TABLE II. CONCEPT AND GEMBIRA DANCE CONTEXT

\begin{tabular}{|c|c|c|}
\hline $\begin{array}{c}\text { Dance } \\
\text { Context }\end{array}$ & $\begin{array}{c}\text { Mathematical } \\
\text { Concept }\end{array}$ & Basic competencies \\
\hline $\begin{array}{l}\text { Counting on } \\
\text { each motion }\end{array}$ & Whole numbers & $\begin{array}{l}\text { Class I: } \\
\text { 3.1 Explain the meaning of a } \\
\text { number with } 99 \text { as many } \\
\text { members to a collection of } \\
\text { objects }\end{array}$ \\
\hline $\begin{array}{l}\text { Jumping } \\
\text { motion and } \\
\text { path motion }\end{array}$ & Number pattern & $\begin{array}{l}\text { Class I: } \\
3.5 \text { Know the pattern of } \\
\text { numbers related to a } \\
\text { collection of objects / } \\
\text { images / movements or } \\
\text { other }\end{array}$ \\
\hline \multirow[t]{2}{*}{$\begin{array}{l}\text { the position } \\
\text { of the dancer }\end{array}$} & 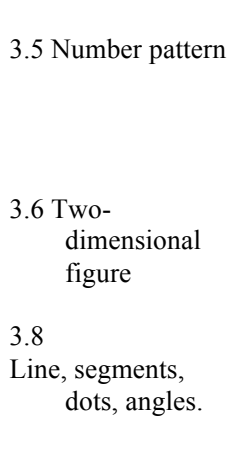 & $\begin{array}{l}\text { Class I: } \\
3.5 \text { Know the pattern of } \\
\text { numbers related to a } \\
\text { collection of objects / } \\
\text { images / movements or } \\
\text { other } \\
\text { 3.6 Get to know the space and } \\
\text { get up flat by using } \\
\text { various concrete objects } \\
\text { Class II: } \\
\text { 3.8 Explain line segments by } \\
\text { using concrete models to } \\
\text { build flat and construct } \\
\text { spaces }\end{array}$ \\
\hline & $\begin{array}{l}\text { 3.9 Shape } \\
\text { characteristics }\end{array}$ & $\begin{array}{l}\text { 3.9 Explain plane shapes and } \\
\text { space based on its } \\
\text { characteristics }\end{array}$ \\
\hline
\end{tabular}




\begin{tabular}{|l|l|l|}
\hline \multicolumn{1}{|c|}{$\begin{array}{c}\text { Dance } \\
\text { Context }\end{array}$} & \multicolumn{1}{|c|}{$\begin{array}{c}\text { Mathematical } \\
\text { Concept }\end{array}$} & \multicolumn{1}{c|}{ Basic competencies } \\
\hline & 3.11 Various angles & $\begin{array}{l}\text { Class III: } \\
3.11 \\
\text { Explain angles, types of angles } \\
\text { (right angles, acute angles, } \\
\text { and obtuse angles), and } \\
\text { units of measurement not } \\
\text { standard }\end{array}$ \\
\hline $\begin{array}{l}\text { Turnover } \\
\text { count for } \\
\text { each } \\
\text { movement }\end{array}$ & multiplication & $\begin{array}{l}\text { Class II: } \\
\text { 3.4 Explain multiplication and } \\
\text { division involving counts } \\
\text { with times up to 100 in } \\
\text { daily life and associate } \\
\text { multiplication and division }\end{array}$ \\
\hline
\end{tabular}

\section{CONCLUSION}

As one of creative dance taught in primary school in Indonesia, we found that Gembira dance involves mathematical concepts. The concepts are numbers and geometry. The number concepts include counting whole numbers, number patterns, and multiplication. While, the geometry concepts are two-dimensional figures, lines, segments, dots, angles, and shape characteristics. Moreover, the dance movement might develop students' spatial ability and counting the instruction could develop their number sense. From this study, we provide examples of mathematical problems with dance contexts that teachers can pose in their classroom using the dance context.

\section{REFERENCES}

[1] B. Cvejic. Choreographing Problems: Expressive concepts in contemporary dance and performance. Springer, 2016.

[2] P.C. Taylor and E. Taylor. (2019). "Transformative STEAM Education for Sustainable Development. Empowering Science and Mathematics for Global Competitiveness", Proceedings of the Science and Mathematics International Conference (SMIC 2018), November 2-4, 2018, Jakarta, Indonesia, 125. CRC Press.

[3] M.M. Mohan. "Mathematics of Dance". Open Journal of Applied \& Theoretical Mathematics (OJATM). Vol 2 No 4, 2016.

[4] P.C. Taylor. Transformative science education. Encyclopedia of Science Education, 1079-1083, 2015.

[5] E.G. Guba and Y.S. Lincoln. Fourth generation evaluation. Sage, 1989.

[6] Mariana, N. (2017). Transforming Mathematics Problems in Indonesian Primary Schools by Embedding Islamic and Indonesian Contexts. Disertasi. Perth Australia: Murdoch University.

[7] D. Haryono. Filsafat Matematika (Suatu Tinjauan Epistemologi dan Filosofis). Alfabeta, 2014.

[8] A.W. Bresnahan. Dancing in Time, 2017.

[9] A. Saleh. Number sense: Belajar Matematika Selezat Cokelat. Bandung: Trans Media Pustaka, 2009. 